\title{
UJI IDENTIFIKASI FARMAKOGNOSTIK TUMBUHAN KEMIRI SUNAN (Aleurites trisperma) DI KEBUN PERCOBAAN UNIVERSITAS MUHAMMADIYAH PALANGKARAYA
}

\section{Pharmacognostic Identification of Kemiri Sunan (Aleurites trisperma) from Experimental Garden of Universitas Muhammadiyah Palangkaraya}

\author{
*Rabiatul Adawiyah \\ Pharmacy Study Program, Universitas Muhammadiyah Palangkaraya, RTA Milono St. Km.1,5 \\ Palangka Raya, Indonesia \\ *e-mail : abi.ubiet@gmail.com
}

\begin{abstract}
ABSTRAK
Obat bahan alam sudah dikenal dan digunakan diseluruh dunia sejak beribu tahun yang lalu. Di Indonesia, penggunaan obat bahan alam yang lebih dikenal sebagai jamu atau obat tradisional, telah meluas sejak zaman nenek moyang hingga kini dan terus dilestarikan sebagai warisan budaya. Kekayaan sumberdaya alam yang kita miliki merupakan aset pembangunan kedepan, permasalahannya bagaimana kita bisa memanfaatkan potensi tersebut secara arif dan bijaksana. Tanaman Kemiri sunan (Aleurites trisperma) merupakan salah satu tanaman yang terdapat di wilayah Indonesia. Kemiri sunan (Aleurites trisperma) adalah nama tanaman yang diberikan terhadap jenis tanaman kemiri racun. Di kalimantan tengah tanaman ini sudah mulai dibudidayakan dibidang pertanian sebagai bioindustri dan pestisida, belum ada ditemukan penelitian tanaman tersebut digunakan sebagai pengobatan. Penelitian ini bertujuan untuk mendapatkan data ilmiah mengenai gambaran farmakognostik tanaman kemiri sunan serta untuk memperkaya inventaris tanaman obat Indonesia, mengetahui golongan kimia simplisia tanaman kemiri sunan. Metode yang digunakan adalah penelitian eksperimen dengan pendekatan laboratorium. Penelitian dilakukan dengan beberapa tahapan uji makroskopis, mikroskopis dan ekstrak daun kemiri sunan diperoleh dengan metode maserasi dan uji lemak menggunakan soxhletasi menggunakan pelarut etanol 96\%. Hasil penelitian pada organoleptis daun berwarna hijau, bau lembut (tidak menyengat), rasa tawar (tidak berasa), pemeriksaan uji pendahuluan kadar air 13.09\%, kadar abu 0.9\%, kadar lemak $7.46 \%$, kadar serat kasar $32.82 \%$ dan hasil skrining fitokimia menunjukkan kandungan senyawa kimia daun kemiri sunan positif mengandung tannin, alkaloid, saponin, steroid dan terpenoid.
\end{abstract}

Kata kunci: Kemiri Sunan, Etanol 96\%, Uji Pendahuluan, Metabolit Sekunder

\begin{abstract}
Natural ingredients have been known and used all over the world since thousands of years ago. In Indonesia, the natural ingredients, better known as herbal or traditional medicine, has been widespread since the time of the ancestors until now and continues to be preserved as a cultural heritage. Wealth of natural resources that we have is an asset of future development, the problem is how we can exploit that potential wisely and wisely. Siri herbs (Aleurites trisperma) is one of the plants in Indonesia. Pecan sunan (Aleurites trisperma) is the name of the plant given to the plant species of pecan poison. In middle kalimantan this plant has started cultivated in the field of agriculture as bioindustri and pesticide, there has been no research of the plant is used as a treatment. This study aims to obtain scientific data about the pharmacognostic picture of the hazelnut plants and to enrich the inventory of Indonesian medicinal plants, knowing the simplicia chemicals group of candlenut crops. The method used is experimental research with laboratory approach. The research was conducted with several stages of macroscopic, microscopic and leafy siri leaves extract obtained by maceration method and fatty test using soxhletasi using $96 \%$ ethanol solvent. The results of the study on green leaf organoleptis, soft odor (no sting), tasting (preliminary), preliminary test of water content $13.09 \%$, ash $0.9 \%$, fat content $7.46 \%$, crude fiber content $32.82 \%$ and phytochemical screening results showed the chemical content of positive sugars leaves contains tannins, alkaloids, saponins, steroids and terpenoids.
\end{abstract}

Keywords: Kemiri Sunan, Ethanol 96\%, Preliminary Test, Secondary Metabolite 


\section{PENDAHULUAN}

Obat bahan alam sudah dikenal dan digunakan diseluruh dunia sejak beribu tahu yang lalu (sidik, 1998). Di Indonesia, penggunaan obat bahan alam yang lebih dikenal sebagai jamu atau obat tradisional, telah meluas sejak zaman nenek moyang hingga kini dan terus dilestarikan sebagai warisan budaya.

Kekayaan sumberdaya alam yang kita miliki merupakan aset pembangunan kedepan, permasalahannya bagaimana kita bisa memanfaatkan potensi tersebut secara arif dan bijaksana. Pengembangan obat alami sebagai salah satu aset yang patut mendapat perhatian yang lebih besar mengingat permintaan pasar tentang bahan baku obat-obatan tradisional terus meningkat untuk kebutuhan domestik maupun internasional. Dengan maraknya gerakan kembali kealam atau back tu nature, kecenderungan penggunaan bahan obat alam/herbal di dunia semakin meningkat.

Gerakan tersebut dilatarbelakangi perubahan lingkungan, pola hidup manusia dan perkembangan pola penyakit. Slogan kembali kealam yang menunjukkan minimnya efek negatif yang ditimbulkan dari penggunaan herbal dan juga ekonomis, menarik minat masyarakat untuk kembali menggunakan obat-obatan dari bahan alami khususnya yang berasal dari tanaman yang berkhasiat dalam pengobatan.

Kemiri sunan (Aleurites trisperma) adalah salah satu tanaman yang sangat potensial sebagai penghasil minyak nabati (Heyne, 1987). Standardisasi dalam farmasi adalah serangkaian parameter, metode dan cara pengukuran yang hasilnya merupakan unsur-unsur terkait dalam mutu kefarmasian.
Pesyaratan mutu dalam simplisia seperti identifikasi kimia dan analisis kuantitatif yang meliputi kadar abu, kadar air, susut pengeringan dan bahan organik asing. Oleh karena itu dalam uji farmakognostik pada daun Kemiri Sunan akan dilakukan serangkaian uji baik secara kualitatif maupun kuantitatif.

\section{METODOLOGI}

\section{Alat dan Bahan}

Bahan yang digunakan pada penelitian ini adalah daun kemiri sunan yan dambil di kebun Percobaan Fakultas Pertanian dan Kehutanan UM Palangkaraya di Jalan Mahir Mahar gang Anggrek seluas 20 ha dengan ketinggian 50 meter dpl bertanah gambut dangkal (kedalaman $100 \mathrm{~cm}$ )., etanol $96 \%$, aquades, $\mathrm{CH}_{3} \mathrm{COOH}, \mathrm{H}_{2} \mathrm{SO}_{4}$, kertas saring dan lain-lain. Alat yang digunakan dalam penelitian adalah maserator, beaker glass, gelas ukur, labu ukur, toples, ayakan, corong, rotari evaporator, pipet tetes, pipet ukur dan lain-lain.

\section{Prosedur}

1. Penyiapan Bahan

Tanaman kemiri sunan diambil bagian daun kemudian dibersihkan, selanjutnya direduksi menjadi ukuran yang lebih kecil kemudian dikeringkan. Daun yang telah dikeringkan ditentukan kadar airnya ( $\leq 10 \%)$.

2. Pembuatan Serbuk Simplisia

Simplisia (bahan) yang telah diketahui kadar airnya $(\leq 10 \%)$ di tumbuk pada lumpang besi sampai halus, diayak dengan ayakan no.10. Serbuk halus di tampung, dan di simpan dalam toples masing-masing diberi nama atau label.

3. Analisis Laboratorium

Penelitian ini dilaksanakan dengan beberapa analisis laboratorium yaitu analisis fitokimia 
dengan reaksi kimia, penentuan kadar air, dan proses pemisahan atau ekstraksi dengan maserasi.

a. Identifikasi dan Analisis Kadar Air serta Kadar Proksimat daun kemiri sunan

Identifikasi dan evaluasi Tanaman kemiri sunan dilakukan sebagai studi pendahuluan (empirical studies) dengan tujuan bahwa tanaman yang diteliti dan digunakan adalah Tanaman kemiri sunan yang selama ini dimanfaatkan oleh masyarakat secara turun-temurun sebagai obat tradisional (Badan POM, 2005).

Penentuan kandungan kadar air dan kadar proksimat daun kemiri sunan merupakan bagian tahapan penelitian pendahuluan, dilakukan untuk menentukan karakteristik serbuk daun kemiri sunan, yang meliputi kadar air, kadar lemak, kadar serat, kadar abu, dan kadar karbohidrat (AOAC, 1995).

b. Penetapan Kadar Air

Cawan proselin dikeringkan dalam oven $105^{\circ} \mathrm{C}$ selama 30 menit, dinginkan dalam eksikator, timbang. Selanjutnya sampel ditimbang sebanyak $5 \mathrm{gr}$. Dalam proselin yang telah diketahui beratnya, oven $105^{\circ} \mathrm{C}$ selama 2 jam, dinginkan dalam eksikator, timbang. Lakukan pengeringan dalam oven $105^{\circ} \mathrm{C}$ dan penimbangan sampai didapatkan bobot tetap.

\section{c. Penetapan Kadar Abu}

Serbuk simplisia, ditimbang sebanyak 2,0 gram secara seksama, masukkan ke dalam krus proselin yang telah dikeringkan sampai bobot tetap. Pijarkan secara perlahan-lahan menjadi abu $\left(150^{\circ} \mathrm{C}\right)$ kemudian dinginkan dan timbang hingga bobot tetap. Kadar abu dihitung terhadap bahan yang telah dikeringkan.

d. Penetapan Kadar Lemak Simplisia ditimbang 2 gr kemudian disoxhletasi dengan pelarut dietil eter selama 6 jam, ekstrak dikeringkan dalam oven $100^{\circ} \mathrm{C}$ selama 30 menit, dinginkan dalam eksikator. Selanjutnya timbang sampai bobot tetap. Selain itu dapat pula dilakukan dengan fat analiser.

e. Penetapan Kadar Serat Kasar Simplisia ditimbang 2 gr kemudian direflux selama 30 menit dengan pelarut Asam Sulfat $1,25 \%$ sebanyak $200 \mathrm{ml}$. Kemudian

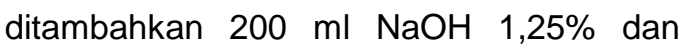
dilanjutkan reflux 30 menit. Saring, filtrat ditampung dan dicuci berturut-turut $20 \mathrm{ml}$ Asam Sulfat 1,25\% $50 \mathrm{ml}$ air panas, $25 \mathrm{ml}$ alcohol. Kemudian kertas saring dikeringkan selama 2 jam pada suhu $130^{\circ} \mathrm{C}$. Dinginkan dan ditimbang.

\section{Analisis Fitokimia}

Simplisia daun kemiri sunan dilakukan analisis fitokimia terhadap beberapa golongan senyawa metabolid sekunder dengan reaksi kimia dengan melihat reaksi warna dan pengendapan. Golongan senyawa kimia yang dianalisis fitokimianya adalak alkaloid, saponin, flavonoid, tanin, steroid dan triterpenoid serta fenol.

1. Pemeriksaan Golongan Flavonoid

Timbang $0,5 \mathrm{~g}$ tambahkan $10 \mathrm{~mL}$ methanol dan panaskan selama 10 menit, saring larutan dalam keadaan panas. Filtrat diencerkan dengan $10 \mathrm{~mL}$ air, kemudian dinginkan. Ambil lapisan methanol dan uapkan pada suhu $40^{\circ} \mathrm{C}$, sisa larutan ditambahkan etil asetat, filtrate diuapkan dan sisa penguapan ditambahkan 2 
$\mathrm{mL}$ etanol $\mathrm{P}$, tambahkan $0,5 \mathrm{~g}$ serbuk seng dan $2 \mathrm{~mL}$ asam klorida $2 \mathrm{~N}$, diamkan selama 1 menit, tambahkan 10 tetes asam klorida pekat. Jika dalam 2-5 menit terjadi warna merah intensif, maka menunjukkan adanya flavonoid.

\section{Pemeriksaan Golongan Fenol}

Dimasukkan $0,5 \mathrm{~g}$ sampel ke dalam tabung reaksi, ditambahkan $5 \mathrm{~mL}$ air suling, lalu panaskan sampai mendidih selama 2 menit, dinginkan dan saring. Filtrate yang diperoleh dimasukkan ke dalam tabung reaksi ditambah larutan besi (III) klorida 1\% akan terbentuk warna hijau atau hitam kehijauan menunjukkan adanya fenol.

3. Pemeriksaan Golongan Alkaloid

Dimasukkan 0,5 g sampel ke dalam tabung reaksi, ditambahkan $1 \mathrm{ml} \mathrm{HCl} 2 \mathrm{~N}$ dan $9 \mathrm{~mL}$ air suling. Lalu panaskan hingga mendidih selama 2 menit, dinginkan lalu filtrate yang diperoleh dimasukkan ke dalam 3 tabung reaksi yang berbeda.

Pada tabung reaksi pertama ditambahkan 2 tetes larutan mayer LP, tabung kedua ditambahkan 2 tetes Bouchadrat LP. Pada tabung ketiga ditambahkan 2 tetes larutan Dragendorf LP. Terbentuk endapan kuning atau endapan putih pada tabung reaksi pertama, endapan kuning coklat pada tabung reaksi ke dua dan endapan merah coklat pada tabung reaksi ke tiga, menunjukkan adanya alkaloid.

4. Pemeriksaan Golongan Saponin

Dimasukkan contoh (ekstrak) ke dalam tabung reaksi sebanyak $0,5 \mathrm{~g}$, ditambahkan $10 \mathrm{~mL}$ air panas, dinginkan dan kocok kuat-kuat selama 10 detik. Terbentuklah buih yang stabil selama tidak kurang dari 10 menit, busa setinggi 1-10 $\mathrm{cm}$. Pada penambahan asam klorida $2 \mathrm{~N}$ busa tidak hilang, menunjukkan adanya golongan saponin.

\section{HASIL DAN PEMBAHASAN}

\section{Pemeriksaan Morfologi Daun Kemiri Sunan}

Hasil pemeriksaan dari morfologi tumbuhan daun kemiri sunan adalah sebagai berikut tumbuhan daun kemiri sunan merupakan tumbuhan yang berupa pepohonan dengan bentuk kanopi memayung yang terkadang juga silindris, tinggi pohon dapat mencapai 15-20 m dengan diameter batang dapat mencapai > $40 \mathrm{~cm}$. Sistem percabangan pada kemiri sunan adalah khas, bercabang tiga atau lebih secara lateral. Daun kemiri sunan termasuk ke dalam daun yang tidak lengkap karena tidak mempunyai bagian daun yang utuh, dimana hanya terdiri dari helaian daun dan tangkai daunnya saja, dan tidak mempunyai pelepah atau upih daun. Daun kemiri sunan mempunyai bentuk menjatung (cordata) dengan tulang daun menyirip serta tekstur permukaan daun yang halus. Daun kemiri sunan tumbuh dan berkembang pada setiap ranting di ujung cabang dengan jumlah 13-21 helaian daun. Daun kemiri sunan memiliki panjang 14-21 cm dan lebarnya 13$20 \mathrm{~cm}$ tergantung umur tanaman, letak daun, dan varietasnya. Daun yang mendapat sinar matahari penuh memiliki ukuran yang lebih luas dibandingkan daun yang terlindung. Warna daun kemiri sunan yang muda bervariasi dari merah, merah kecoklatan dan hijau muda tergantung varietasnya. 


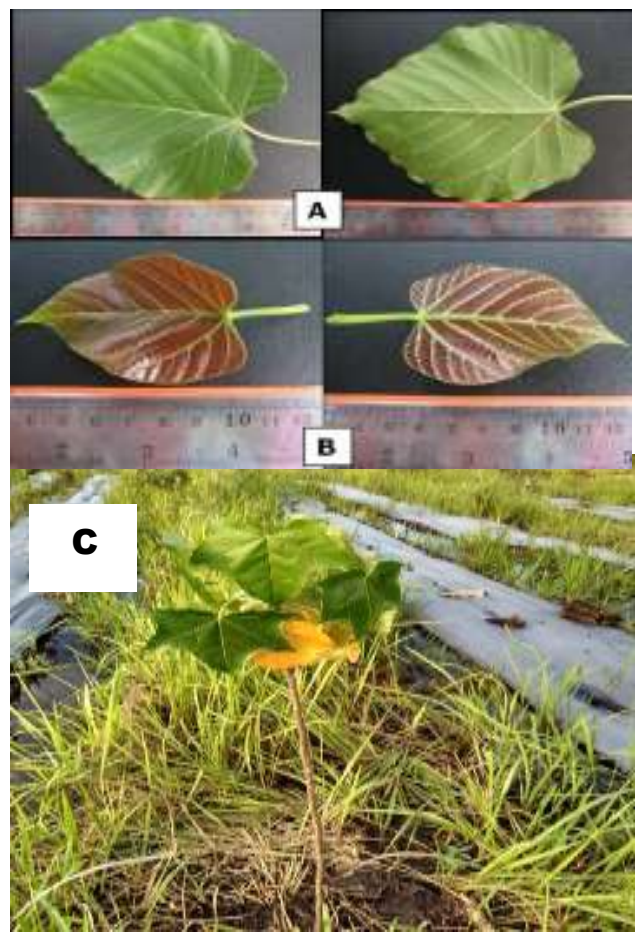

Gambar 1. Tanaman Kemiri Sunan

Keterangan :

A. Bentuk Daun Tua

B. Bentuk Daun Muda

C. Bagian Daun dan Batang

\section{Pemeriksaan Anatomi Daun Kemiri Sunan}

Hasil pemeriksaan anatomi daun kemiri sunan dapat dilihat dari penampang melintang dan penampang membujur. Perbesaran yang digunakan pada pemeriksaan ini adalah perbesaran 10X dan 40X. hasil dari pemeriksaan anatomi daun kemiri sunan dapat dilihat pada Gambar 2.

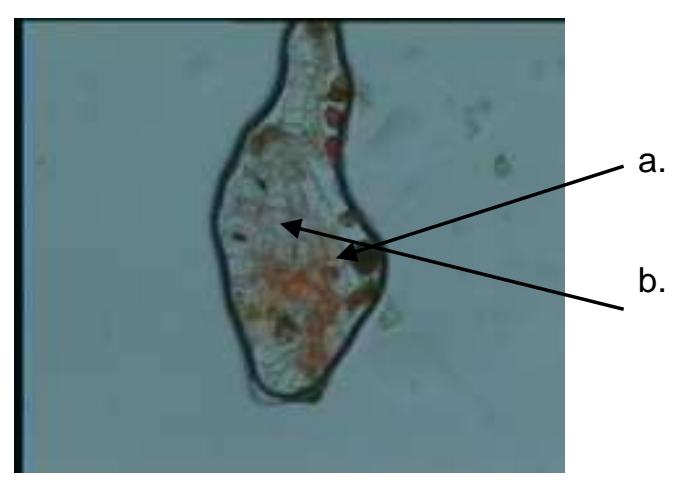

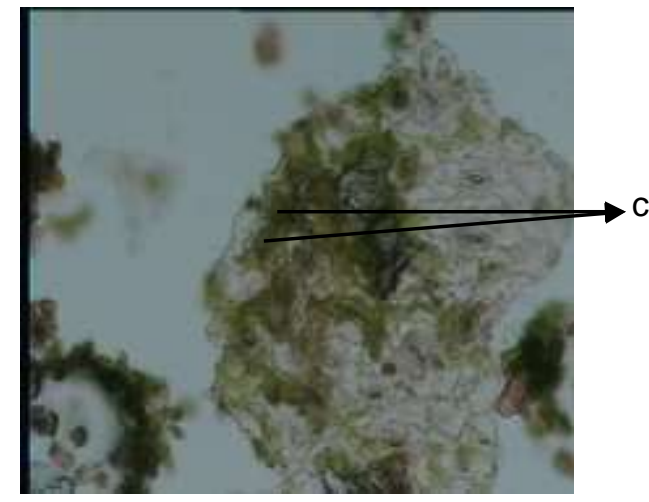
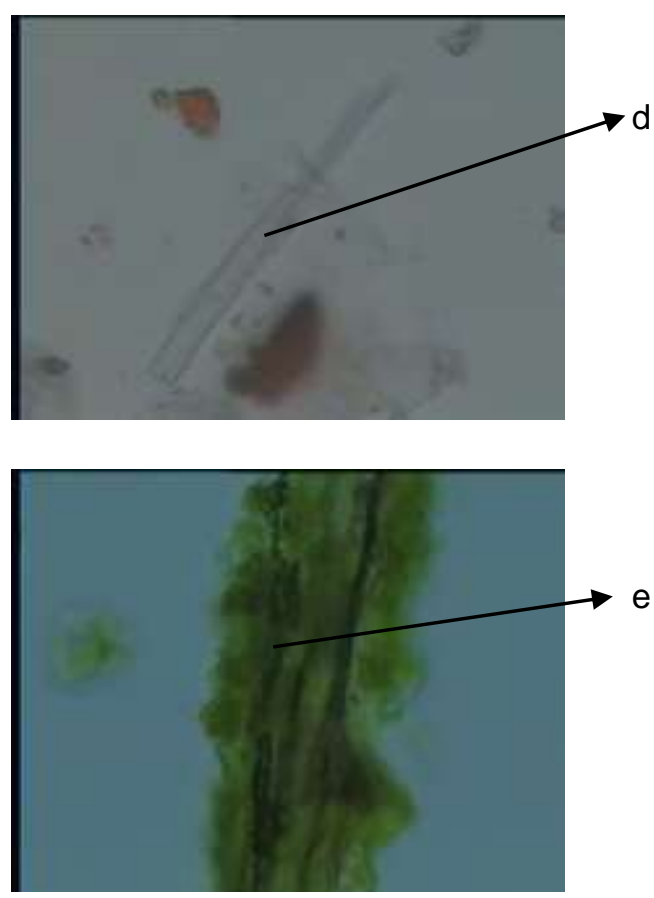

Gambar 2. Pemeriksaan Anatomi Daun Keterangan :

a. Parenkim dengan sel batu dan sel minyak

b. stomata

c. Epidrmis dan Stomata

d. Serabut

e. Berkas pengangkut

\section{Pemeriksaan Organoleptis Daun Kemiri}

Pemeriksaan organoleptis daun Kemiri sunan dilakukan terhadap warna, bau dan rasanya. Hasil pemeriksaan organoleptis daun kemiri sunan dapat dilihat pada Tabel 1. 
Tabel I. Hasil pemeriksaan organoleptis daun kemiri sunan

\begin{tabular}{|c|c|c|c|}
\hline $\begin{array}{c}\text { Bagian } \\
\text { yang } \\
\text { digunakan }\end{array}$ & Warna & Bau & Rasa \\
\hline Daun & Hijau & $\begin{array}{c}\text { Lembut } \\
\text { (tidak } \\
\text { menyengat) }\end{array}$ & $\begin{array}{l}\text { Tawar } \\
\text { (tidak } \\
\text { berasa) }\end{array}$ \\
\hline
\end{tabular}

Hasil yang diperoleh dari Tabel 1 menunjukkan karakteristik dari daun kemiri sunan yang dilakukan secara organoleptis dan pengujian dilakukan secara subjektif.

\section{Pemeriksaan Uji Pendahuluan Daun Kemiri Sunan}

Berdasarkan hasil penelitian uji pendahuluan daun kemiri sunan yaitu kadar air, kadar abu, kadar lemak, dan kadar serat kasar dapat dilihat pada tabel 2 sebagai berikut:

Tabel II. Uji Pendahuluan daun Kemiri Sunan

\begin{tabular}{clc}
\hline No. & Parameter & Hasil \\
\hline 1 & Kadar Air & $13.09 \%$ \\
2 & Kadar Abu & $0.9 \%$ \\
3 & Kadar Lemak & $7.46 \%$ \\
4 & Kadar Serat Kasar & $32.82 \%$ \\
\hline Sumber : Data primer yang diolah
\end{tabular}

Berdasarkan tabel di atas kadar air yang dihasilkan dari daun kemiri sunan yaitu sebesar 13,09\% dan untuk kadar abu yang dihasilkan dari tumbuhan kemiri sunan yaitu sebesar 0,9\%. Dimana kandungan air yang cukup tinggi sangat dipengaruhi oleh beberapa faktor yaitu umur tanaman, kelembapan udara, faktor lingkungan dan kondisi penyimpanan, sedangkan kadar abu dipengaruhi oleh curah hujan, kondisi tanah, pupuk, dan faktor-faktor lainnya (deMan, 1997). Sedangkan hasil penelitian untuk kadar lemak dan kadar serat kasar yaitu $7,46 \%$ dan 32,82\%. Menurut Badan Standarisasi Nasional (2006), Kadar lemak untuk jenis tanaman adalah $0.8 \%$ sedangkan dari hasil penelitian tentang daun kemiri sunan adalah sebesar $7,46 \%$. Dari hasil tersebut bahwa daun kemiri sunan tidak dapat digunakan sebagai bahan baku minyak. Hal ini disebabkan oleh beberapa faktor yang mepengaruhinya seperti tempat tumbuh, iklim, dan faktor lingkungan. Kadar serat kasar dalam literatur dijelaskan bahwa serat kasar merupakan serat pangan yang tidak larut dalam asam maupun basa, oleh karena itu dalam penelitian ini, analisisnya dilakukan dengan penambahan $\mathrm{H}_{2} \mathrm{SO}_{4} 1,25 \%$ $(0,255 \mathrm{~N})$ bertujuan melarutkan zat lain yang dapat larut dalam asam, demikian pula dengan penambahan $\mathrm{NaOH} 1,25 \%$ yang bertujuan untuk melarutkan zat-zat yang larut dalam basa yang tidak larut dalam asam dan aquadest yang mendidih untuk menghilangkan kelebihan $\mathrm{NaOH}$ dalam residu.

Hasil nilai penelitian kadar serat kasar adalah $32,82 \%$ dengan dibandingkan menurut Piliang dan Djojosoebagio adalah kandungan serat kasar terdiri dari hemisellulosa, $50-90 \%$ untuk lignin dan 20-50\% untuk sellulosa. Hal ini dikarenakan kadar serat kasar juga terdiri dari karbohidrat yang mana tidak dapat dihidrolisa oleh enzim-enzim pencernaan pada manusia. Sisa yang tidak dicerna ini dikenal dengan diet serat kasar yang kemudian melewati saluran pencernaan dan dibuang dalam feses. Serat makanan ini terdiri dari dinding sel tanaman yang sebagian besar mengandung 3 macam polisakharida yaitu sellulosa, zat pectin dan hemisellulosa. Selain itu juga mengandung zat yang bukan karbohidrat yakni lignin (Piliang dan Djojosoebagio, 2002).

\section{Fitokimia}

Ekstraksi daun kemiri sunan pada penelitian ini menggunakan metode maserasi. Maserasi 
dilakukan untuk mendapatkan ekstrak tanaman yang akan dijadikan sebagai bahan uji. Pada pengujian alkaloid, tanin, steroid dan terpenoid yang digunakan adalah ekstrak kental dari daun kemiri sunan. Sedangkan untuk uji flavonoid dan saponin digunakan ekstrak cairnya.

Pelarut yang digunakan untuk merendam simplisia adalah ethanol 95\%. Ethanol dipertimbangkan sebagai penyari, karena bersifat universal, kapang dan kuman lebih sulit tumbuh dalam ethanol $20 \%$ ke atas, tidak netral, absorbsinya baik, dan juga etanol dapat bercampur dengan air pada segala perbandingan dan panas yang diperlukan untuk pemekatan jauh lebih sedikit. Ethanol dapat melarutkan alkaloid, minyak menguap, glikosida, kurkumin, antrakinon, flavonoid dan steroid. Ekstrak cair yang didapatkan dari hasil maserasi ini berwarna hijau jernih.

Setelah didapatkan ekstrak cair hasil maserasi, ekstrak cair tersebut diambil untuk dibuat menjadi ekstrak kental dengan menyisahkan $5 \mathrm{~mL}$ ekstrak cair untuk identifikasi flavonoid dan saponin. Ekstrak kental ini dibuat dengan cara menguapkan ekstrak cair di atas waterbath atau penangas air hingga ekstrak cair tersebut menjadi kental. Tujuannya agar ethanol yang digunakan sebagai pelarut zat-zat aktif pada saat maserasi dapat menguap dan yang tersisa hanya murni ekstrak dari daun kemiri sunan tersebut. Ekstrak kental ini berwarna coklat kehitaman.

Dari hasil proses maserasi dengan ethanol $95 \%$ selama 3 hari diperoleh ekstrak kental dan ektrak cair, selanjutnya dilakukan proses identifikasi fitokimia pada masing-masing ekstrak dengan menggunakan pereaksi yang sesuai dan memperoleh hasil yang dapat dilihat pada Tabel 3 sebagai berikut.
Tabel III. Hasil Skrining Fitokimia Daun Kemiri Sunan

\begin{tabular}{|c|c|c|c|c|c|}
\hline No. & $\begin{array}{l}\text { Senyawa } \\
\text { yang } \\
\text { Diuji }\end{array}$ & $\begin{array}{c}\text { Pereak } \\
\text { si yang } \\
\text { digunak } \\
\text { an }\end{array}$ & $\begin{array}{c}\text { Hasil Standar } \\
\text { sesuai } \\
\text { (Materia } \\
\text { Medika } \\
\text { Indonesia) }\end{array}$ & $\begin{array}{c}\text { Hasil } \\
\text { Pengama } \\
\tan \end{array}$ & $\begin{array}{c}\mathrm{Ke} \\
\mathrm{t}\end{array}$ \\
\hline \multirow[t]{2}{*}{1.} & Tanin & $\begin{array}{c}\mathrm{FeCl}_{3} \\
\text { tambah }\end{array}$ & $\begin{array}{c}\text { Berwarna } \\
\text { hitam }\end{array}$ & $\begin{array}{l}\text { Larutan } \\
\text { hijau }\end{array}$ & \\
\hline & & $\begin{array}{l}\text { albumin } \\
\text { (putih } \\
\text { telur) }\end{array}$ & $\begin{array}{l}\text { kehijauan atau } \\
\text { biru gelap }\end{array}$ & $\begin{array}{l}\text { kehitama } \\
\text { n dan } \\
\text { endapan }\end{array}$ & + \\
\hline \multirow[t]{3}{*}{2 . } & Alkaloid & $\begin{array}{l}\text { Dragen } \\
\text { droff }\end{array}$ & $\begin{array}{c}\text { Terdapat } \\
\text { adanya } \\
\text { endapan } \\
\text { merah bata }\end{array}$ & $\begin{array}{l}\text { Terbentu } \\
\text { k } \\
\text { endapan } \\
\text { merah }\end{array}$ & - \\
\hline & & Meyer & $\begin{array}{l}\text { Endapan } \\
\text { menggumpal } \\
\text { berwarna } \\
\text { putih atau } \\
\text { kuning }\end{array}$ & $\begin{array}{l}\text { Terbentu } \\
\text { k } \\
\text { endapan } \\
\text { putih }\end{array}$ & + \\
\hline & & $\begin{array}{l}\text { Boucha } \\
\text { rdat }\end{array}$ & $\begin{array}{c}\text { Endapan } \\
\text { cokelat } \\
\text { sampai hitam }\end{array}$ & $\begin{array}{l}\text { Terbentu } \\
\text { k } \\
\text { endapan } \\
\text { cokelat }\end{array}$ & + \\
\hline 3. & Saponin & $\begin{array}{l}\mathrm{HCL} \\
2 \mathrm{~N}\end{array}$ & $\begin{array}{l}\text { Terbentuk } \\
\text { buih mantap } \\
\text { selama tidak }\end{array}$ & $\begin{array}{l}\text { Buih } \\
\text { tidak } \\
\text { hilang }\end{array}$ & \\
\hline & & & $\begin{array}{c}\text { kurang dari } 10 \\
\text { menit }+\mathrm{HCL} \\
2 \mathrm{~N} \text { Buih tidak } \\
\text { hilang }\end{array}$ & & + \\
\hline 4. & Flavonoid & $\begin{array}{l}\text { Serbuk } \\
\text { Magne } \\
\text { sium } \\
\text { dan } \\
\text { HCL }\end{array}$ & $\begin{array}{l}\text { Jika terjadi } \\
\text { warna merah } \\
\text { jingga sampai } \\
\text { merah ungu, } \\
\text { menunjukkan } \\
\text { flavonoid. }\end{array}$ & $\begin{array}{c}\text { Warna } \\
\text { menjadi } \\
\text { bening, } \\
\text { tidak } \\
\text { menimbul } \\
\text { kan } \\
\text { warna } \\
\text { jingga } \\
\text { sampai } \\
\text { ungu } \\
\text { merah }\end{array}$ & - \\
\hline 5. & $\begin{array}{l}\text { Steroid } \\
\text { dan } \\
\text { Terpenoid }\end{array}$ & $\begin{array}{c}\text { Asam } \\
\text { Asetat } \\
\text { Anhidra } \\
\text { t dan } \\
\text { Asam } \\
\text { Sulfat } \\
\text { Pekat }\end{array}$ & $\begin{array}{c}\text { Tidak } \\
\text { terbentuk } \\
\text { larutan merah } \\
\text { yang } \\
\text { kemudian } \\
\text { menjadi biru } \\
\text { dan hijau. }\end{array}$ & $\begin{array}{c}\text { Terbentu } \\
\text { k warna } \\
\text { larutan } \\
\text { cokelat } \\
\text { kehitama } \\
\text { n }\end{array}$ & + \\
\hline
\end{tabular}

a. Identifikasi Tanin

Pada identifikasi tanin yaitu dengan menimbang ekstrak kental sebanyak 0,511 gram ditambah dengan $50 \mathrm{ml}$ air kemudian dipanaskan di atas penangas air selama 30 menit sambil diaduk hingga mendidih. Diamkan beberapa saat lalu saring, kemudian diambil filtrat sebanyak 5 tetes dan dimasukkan ke dalam tabung reaksi. Larutan kemudian direaksikan dengan 2 tetes larutan $\mathrm{FeCl}_{3}$, dan hasilnya terbentuk larutan yang berwarna coklat kehitaman. Pada uji menggunakan albumin dalam hal ini diganti dengan putih telur 
terdapat adanya endapan pada larutan uji. Ini menandakan bahwa sampel positif mengandung tanin.

Tanin membentuk senyawa larut dalam air berwarna hitam kehijauan atau biru gelap. Dipercayai bahwa tanin dapat memberikan perlindungan terhadap serangan mikroba (Nahar Luftun dan Sarker.D. Satyajit. 2009).

b. Identifikasi Alkaloid

Pada identifikasi alkaloid dengan menimbang ekstrak kental sebanyak 0,514 gram, kemudian ditambahkan dengan $1 \mathrm{ml}$ asam klorida dan 9 $\mathrm{ml}$ air suling. Panaskan selama 2 menit, lalu dinginkan dan disaring. Hasil saringan kemudian diambil sebanyak 2 tetes ke dalam tabung reaksi dan diuji dengan pereaksi Dragendroff, Meyer dan Bouchardat untuk masing-masing bahan uji sebanyak 3 tetes.

Bahan uji dengan penambahan pereaksi Dragendroff tidak terbentuk endapan merah jingga yang artinya negatif mengandung alkaloid. Pada bahan uji dengan penambahan pereaksi Meyer terbentuk endapan putih kekuningan yang berarti hasilnya positif mengandung alkaloid. Dan pada penetesan pereaksi Bouchardat terbentuk endapan coklat yang menyatakan hasilnya positif mengandung alkaloid. Jadi, identifikasi alkaloid pada tumbuhan daun kemiri sunan dinyatakan positif mengandung alkaloid. Sejumlah alkaloid alami dan turunannya telah dikembangkan sebagai obat untuk mengobati berbagai macam penyakit seperti morfin, reserpin dan taxol (Gunawan, Didik dan Mulyani, Sri. 2004).

c. Identifikasi Saponin

Pada identifikasi saponin dengan mengambil ekstrak cair sampel sebanyak $1 \mathrm{ml}$ dan diencerkan dengan aquadest sebanyak $10 \mathrm{ml}$, lalu dikocok kuat-kuat selama 10 detik, yang kemudian terbentuk buih yang mantap selama tidak kurang dari 10 menit. Lalu pada penambahan 1 tetes asam klorida $2 \mathrm{~N}$, buih tidak hilang, yang artinya sampel ini positif mengandung saponin. Saponin memiliki kegunaan dalam pengobatan, terutama karena sifatnya yang mempengaruhi absorpsi zat aktif secara farmakologi (Gunawan, Didik dan Mulyani, Sri. 2004).

\section{d. Identifikasi Flavonoid}

Pada identifikasi flavonoid sebanyak $1 \mathrm{ml}$ ekstrak cair ditambahkan dengan 1,012 gram serbuk Mg (Magnesium) dan beberapa tetes (12 tetes) HCL pekat. Jika terjadi warna merah jingga sampai merah ungu, menunjukkan adanya flavonoid. Hasil yang diperoleh tidak terdapatnya warna merah jingga pada daun kemiri sunan sehingga diperoleh hasil negatif untuk identifikasi flavonoid.

Pada Tabel III hasil uji skrining fitokimia pada daun Kemiri Sunan menunjukkan hasil positif tannin, alkaloid, saponin, steroid dan triterpenoid.

Penelitian yang dilakukan pada daun kemiri sunan dengan melakukan uji farmakognostik yaitu bertujuan untuk memperoleh informasi secara lebih rinci mengenai cirri-ciri dari suatu tanaman baru yang nantinya informasi yang didapat tersebut digunakan sebagai acuan dalam penelitian selanjutnya. Tanaman kemiri sunan yang termasuk kedalam salah satu tanaman baru yang lebih dikenal masyakat sebagai penghasil biodissel teryata juga mempunyai suatu khasiat yang dapat dimanfaatkan sebagai obat tradisional. Identifikasi yang dilakukan secara farmakognostik meliputi analisis makroskopis, analisis 
mikroskopis, uji pendahuluan dengan dilakukan uji pemeriksaan kadar air, kadar abu, serat kasar, kadar lemak dan uji fitokimia.

\section{KESIMPULAN}

Makroskopis daun kemri sunan yaitu berwarna hijau, mempunyai bau yang lembut dan rasa yang tawar. Pada bagian mikroskopis daun kemiri sunan menunjukkan adanya stomata, parenkim dan jaringan epidermis yang terdapat warna kuning. Golongan senyawa yang terkandung pada daun kemiri sunan adalah tannin, alkaloid, saponin, steroid dan triterpenoid. Penelitian selanjutnya dapat dilakukan untuk mengisolasi golongan senyawa kimia yang mempunyai aktivitas antibakteri pada kemiri sunan.

\section{DAFTAR PUSTAKA}

Anonim. 1978. Materia Medika Indonesia. Depkes RI. Jakarta

Anonim. 1987. Analisis Obat Tradisional. Depkes RI. Jakarta

Anonim. 2004. Ekstrak Tumbuhan Obat Indonesia Vol. 1. Badan pengawasan Obat dan makanan RI. Jakarta

AOAC, H.C. 1989. Official Methods Of Analysis of The Association of Official of Analitical Chemist. Washington.

Anonim. 2005. Peraturan Perundang-undangan dibidang Obat Tradisional, Obat herbal Terstandar dan Fitokimia pp 121. Badan POM. Jakarta

Gunawan, D., \& Sri, M. 2004. Ilmu Obat Alam (Farmakognosi). Penerbit Swadana. Jakarta.

Hamid, A., 1991. Tanaman Kemiri. Edisi Khusus Littro Vol. VII (2)
Harborne, J.B. 1987. Metode Fitokimia (Terjemahan Kosasi Patmawinata dan Iwan Soediro). Terbitan Ke-2. ITB. Bandung

Heyne, K. 1987. Tumbuhan Berguna Indonesia Jilid II. Badan Litbang Kehutanan. Jakarta.

Herman,M., Syakir, M., Pranomo, D., Saefudin, \& Sumanto. 2013. Kemiri sunan (Reutealis trisperma (Blanco) Airy Shaw) Tanaman Penghasil Minyak Nabati Dan Konservasi Lahan. IAARD Press. Jakarta.

Sidik. 1998. Perkembangan pemanfaatan Tumbuhan Obat Indonesia. Makalah seminar pengobatan tradisional, FK Unpad. Bandung. 